\title{
Isotopes \& Geochemistry: Tools For Geothermal Reservoir Characterization (Kamchatka Examples)
}

\author{
Alexey Kiryukhin ${ }^{1, *}$, Pavel Voronin ${ }^{1}$, Nikita Zhuravlev $^{1}$, Andrey Polyakov ${ }^{1}$, Tatiana \\ Rychkova $^{1}$, Vasily Lavrushin ${ }^{2}$, Elena Kartasheva ${ }^{1}$, Natalia Asaulova ${ }^{3}$, Larisa \\ Vorozheikina $^{3}$, and Ivan Chernev $^{4}$ \\ ${ }^{1}$ Institute of Volcanology \& Seismology FEB RAS, Piip 9, Petropavlovsk-Kamch., 683006, Russia \\ ${ }^{2}$ Geological Institute RAS, Pyzhevsky 7, Moscow 119017, Russia \\ ${ }^{3}$ Teplo Zemli JSC, Vilyuchinskaya 6, Thermalny, 684000, Russia \\ ${ }^{4}$ Geotherm JSC, Ac. Koroleva 60, Petropavlovsk-Kamchatsky, 683980, Russia
}

\begin{abstract}
The thermal, hydrogeological, and chemical processes affecting Kamchatka geothermal reservoirs were studied by using isotope and geochemistry data: (1) The Geysers Valley hydrothermal reservoirs; (2) The Paratunsky low temperature reservoirs; (3) The North-Koryaksky hydrothermal system; (4) The Mutnovsky high temperature geothermal reservoir; (5) The Pauzhetsky geothermal reservoir. In most cases water isotope in combination with $\mathrm{Cl}^{-}$transient data are found to be useful tool to estimate reservoirs natural and disturbed by exploitation recharge conditions, isotopes of carbon-13 (in $\mathrm{CO}_{2}$ ) data are pointed either active magmatic recharge took place, while $\mathrm{SiO}_{2}$ and $\mathrm{Na}-\mathrm{K}$ geothermometers shows opposite time transient trends (Paratunsky, Geysers Valley) suggest that it is necessary to use more complicated geochemical systems of water/mineral equilibria.
\end{abstract}

\section{Introduction}

Active pore space limitation mass transport velocities are typically greater than heat transport velocities. That is a fundamental reason why changes in the isotope and chemistry parameters of geofluids are faster than changes in the heat properties of producing geothermal reservoirs, which makes them pre-cursors to production parameter changes. In cases of inactive to rock chemical species, they can be used as tracers of fluid flow and boundary condition estimation. Otherwise, chemical equilibriums between rocks, water and gas phases yield reliable chemical signatures of temperature and phase saturation parameters of geothermal reservoirs and internal condition estimation. A gas partial pressure rise reduces the boiling temperature, which may switch reservoirs into two-phase conditions and cycling.

\footnotetext{
*Corresponding author: AVKiryukhin2@mail.ru
} 


\section{The Geysers Valley hydrothermal reservoirs}

The Geysers Valley hydrothermal system (Kamchatka, Russia) is one of the five major geysers fields in the world. The 1941-2018 period of the Valley of Geysers monitoring (Kamchatka, Kronotsky Reserve) reveals a very dynamic geyser behavior in natural state conditions: significant changes of interval between eruptions (IBE) and power of eruptions, chloride concentration and that of other chemical components, and pre-eruption bottom temperature $[1,2,3]$. Nevertheless, the total deep thermal water discharge (that was estimated by the chloride method [1]) remains relatively stable implying that this dynamic behavior may be caused by a redistribution of the thermal discharge due to the Giant Landslide of June 3, 2007, the mudflow of January 3, 2014 and other events of geothermal caprock erosion and water injection into the geothermal reservoir. In some cases, water chemistry and isotope data suggest a local meteoric water influx into the geothermal reservoir and geyser conduits. A local TOUGH2 model of the Velikan geyser is developed and is successfully calibrated against temperature observations at both mid-height and base of the Velikan Geyser conduit, which indicates the essential role of $\mathrm{CO}_{2}$ in the geyser functionality. TOUGHREACT V.3 modeling of the Velikan geyser chemical history confirms a 20\% dilution of deep recharge water and $\mathrm{CO}_{2}$ components after 2014. Temperature logging in the geysers Velikan $(1994,2007,2015,2016,2017,2018)$ and Bolshoy $(2015,2016,2017,2018)$ conduits shows pre-eruption temperatures below boiling at the corresponding hydrostatic pressure, which means the partial pressure of $\mathrm{CO}_{2}$ and other non-condensable gases creating gas-lift upflow conditions in geyser conduits. The Velikan geyser IBE history is explained in terms of a gradual $\mathrm{CO}_{2}$ recharge decline (19412013), followed by a $\mathrm{CO}_{2}$ recharge significant dilution after the mudflow of January 3, 2014 also reshaped geyser conduit and diminished its power.

\section{The Paratunsky low temperature reservoirs}

The Paratunsky low temperature geothermal field has been operated since 1964. During the period of utilization from 1966-2014, $321 \mathrm{Mt}$ of thermal water (Cl-Na, Cl-SO $4-\mathrm{Na}$ composition, TDS up to $2600 \mathrm{ppm}$ ) with temperatures of $70-100^{\circ} \mathrm{C}$ was extracted and used for district heating, balneology and greenhouses [4]. Water isotope and gas $\left(\mathrm{N}_{2}, 96-98 \%\right)$ data analysis indicated that the main recharge region of the Paratunsky geothermal reservoirs is the Viluychinsky Volcano (2173 masl) and the adjacent highly elevated structures, located $25 \mathrm{~km}$ south from the geothermal field. TOUGH 2 modeling of the thermo-hydrodynamic natural state and the history of utilization (involving pressure, temperature and chemical change response to utilization) between 1965 and 2014 yield estimates of hot water upflow rates $(190 \mathrm{~kg} / \mathrm{s})$. Modeling of the chemical (Cl-) history of utilization provides an explanation of a gradual Cl- accumulation due to the inflow of chloride-containing water through the eastern (open) boundary of the geothermal reservoirs (NP \& N sites).

An additional feature is a trend of $\mathrm{T}_{\mathrm{SiO} 2}$ increase $\left(12{ }^{\circ} \mathrm{C} / 50\right.$ years $)$ and a trend of $\mathrm{T}_{\mathrm{Na}-\mathrm{K}}$ decrease $\left(-35^{\circ} \mathrm{C} / 50\right.$ years), while a $\mathrm{pH}$ drop (from 8.1 to 7.1 in 50 years) was observed at the SR1 site of the Paratunsky geothermal field (in the southwest part of the field) (Fig. 1), that may be associated with the influx of more acidic water.

\section{The North-Koryaksky hydrothermal system}

The Avachinsky-Koryaksky volcanogenic basin of an area of $2530 \mathrm{~km}^{2}$, is located $25 \mathrm{~km}$ from Petropavlovsk-Kamchatsky City and includes five Quaternary volcanoes (two of 
which, Avachinsky (2750 masl) and Koryaksky (3456 masl), are active), and is located within a depression that has formed atop Cretaceous basement rocks [5]. Water isotope $\left(\delta \mathrm{D}, \delta^{18} \mathrm{O}\right)$ data indicate that these volcanoes act as recharge areas for their adjacent thermal mineral springs (Koryaksky Narzans, Isotovsky and Pinachevsky) and the wells of the Bystrinsky and Elizovo aquifers. Carbon $\delta^{13} \mathrm{C}$ data for $\mathrm{CO}_{2}$ from $\mathrm{CO}_{2}$ springs in the northern foothills of the Koryaksky Volcano reflect the magmatic origin of $\mathrm{CO}_{2}$. Carbon $\delta^{13} \mathrm{C}$ data for methane $\mathrm{CH}_{4}$ reservoirs penetrated by wells in the Neogene-Quaternary layer around Koryaksky and Avachinsky volcanoes indicate a thermobiogenic origin for methane.

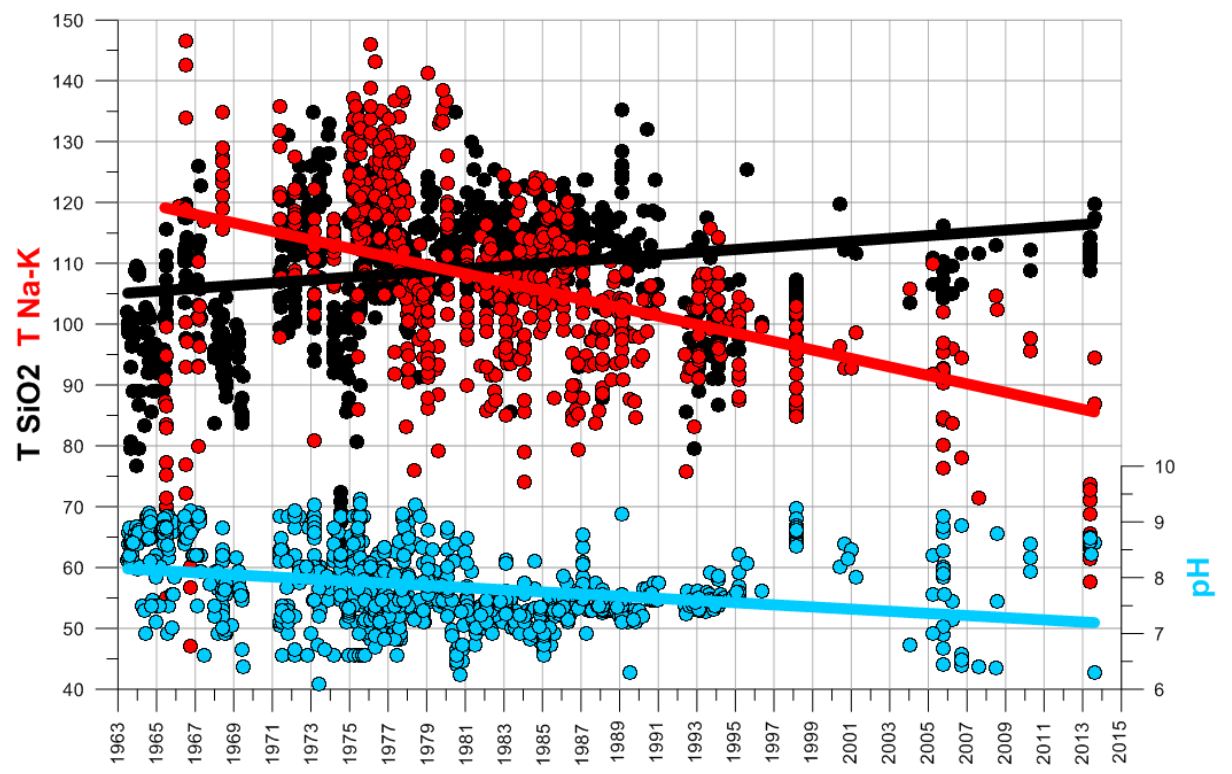

Fig. 1. Chemical history of the SR1 site Paratunsky geothermal field in terms of $\mathrm{Na}-\mathrm{K}$ and $\mathrm{SiO}_{2}$ geothermometers and $\mathrm{pH}$.

\section{The Mutnovsky high temperature geothermal reservoir}

The Mutnovsky geothermal area is a part of the Eastern Kamchatka active volcano belt. Mutnovsky is $80 \mathrm{kY}$ old, an aging strato-volcano (a complex of 4 composite volcanic cones), which acts as a magma- and water-injector into the $25-\mathrm{km}$-long North Mutnovsky extension zone [6]. Magmatic injection events (dykes) are associated with plane-oriented MEQ (microearthquake) clusters, most of whom occur in the NE sector of the volcano $(2 \mathrm{x}$ $10 \mathrm{~km}^{2}$ ) at elevations from -4 to $-2 \mathrm{~km}$, while some magmatic injections take place at elevations from -6.0 to $-4.0 \mathrm{~km}$ below the Mutnovsky production field. The Mutnovsky (Dachny) $260-310^{\circ} \mathrm{C}$ high-temperature production geothermal reservoir with a volume of $16 \mathrm{~km}^{3}$ is at the junction of NNE- and NE-striking normal faults coincides with the current dominant dyke injection orientation. TOUGH2-modeling has been used to estimate the reservoir properties, including the deep upflow recharge of $80 \mathrm{~kg} / \mathrm{s}$ with an enthalpy of $1420 \mathrm{~kJ} / \mathrm{kg}$. Modeling was used to reproduce the history of the Mutnovsky (Dachny) reservoir utilization since 1983 and shows that the predicted power is sensitive to local meteoric water influx during development.

Production geothermal well isotope $\left(\delta \mathrm{D}, \delta^{18} \mathrm{O}\right)$ ratio data clearly indicate the following. 1. The melting glacier of the Mutnovsky volcano is the most probable water recharge area 
for the producing geothermal reservoirs in the Mutnovsky geothermal area, and 2. Some trends in isotope $\left(\delta \mathrm{D}, \delta^{18} \mathrm{O}\right)$ ratios increases during the 12 -year utilizationn period $(5.5 \%$ in $\delta \mathrm{D})$ may have been caused by heavy local groundwater infiltration into the producing geothermal reservoirs (which coincide with chloride dilution trend in production wells and adjacent hot springs). It is noteworthy that the Giggenbach (1988) geo-indicator plot $(\mathrm{K} / 100, \mathrm{Na} / 1000, \operatorname{sqrt}(\mathrm{Mg}))$ also shows some nonequilibrium trends in recent years for wells 048, Geo-1, 022, and 035 and thermal features. Chloride water dilution trend, which is similar to that in production wells, is observed in the Nizhne-Zhirovskoy hot spring, where chloride concentration declined from 120 to $80 \mathrm{ppm}$ from 1985 to 2016 . We do not discuss possible additional mechanisms of isotope $\left(\delta \mathrm{D}, \delta^{18} \mathrm{O}\right)$ ratios enrichment here, since no indications of reinjected water return to production wells or significant production reservoir boiling have been observed recently. Sodium chloride hot springs in the Mutnovsky geothermal area (Nizhne-Zhirovskoy and Vilyuchinsky springs) seem to be a product of the separation of high-temperature geothermal fluids being recharged from the producing geothermal reservoir. Its isotope $\left(\delta \mathrm{D}, \delta^{18} \mathrm{O}\right)$ ratios vary in the range $-103 \%_{0}<\delta \mathrm{D}$ $<-99.9 \%$ and $-15.7 \%$ < $<\delta^{18} \mathrm{O}<-13.4 \%$ (Nizhne-Zhirovskoy), and $-104.3 \%<<\mathrm{D}<$ $-102 \%$ and $-14.3 \%$ o $<\delta^{18} \mathrm{O}<-13.8 \%$ (Vilyuchinsky, well R27). If phase corrections (steam losses at an initial enthalpy of $1260 \mathrm{~kJ} / \mathrm{kg}$ and atmospheric pressure) are applied, these springs $(-111.3 \%,-15.9 \%)$ match the isotope $\left(\delta \mathrm{D}, \delta^{18} \mathrm{O}\right)$ ratios of the Mutnovsky glacier melting water $(-108 \%,-14.9 \%$ ).

We also report the magmatic signs in the gas composition sampled in the Mutnovsky production wells and thermal features, especially in the production reservoir parts adjacent to the Mutnovsky volcano dyke injection zones. The $\delta^{13} \mathrm{C}\left(\mathrm{CO}_{2}\right)$ values in wells 022,031 , 035, A4, and R27 and thermal features Medvejy and Verkhne-Mutnovsky vary in the range $-8.4 \%$ o to $-5.6 \%$, which is indicative of a magmatic origin for the $\mathrm{CO}_{2}$.

\section{The Pauzhetsky geothermal reservoir}

The initial chemistry of the geothermal fluids produced is characterized by its $\mathrm{NaCl}$ and $\mathrm{CO}_{2}-\mathrm{N}_{2}$ concentrations, with a total dissolved solids concentration of $2.7-3.4 \mathrm{~g} / \mathrm{kg}$, and a non-condensable gas concentration of $0.04-0.08 \%$ (by weight). The stable isotope $(\delta \mathrm{D}$, $\delta^{18} \mathrm{O}$ ) ratios of the hot fluids correspond to the range determined in Kurile Lake waters (at 110 masl) and in the cold springs on the Kambalny Ridge (at 600-700m asl), which demonstrates their meteoric origin [7,8]. The fluid enthalpy versus chloride diagram [7] illustrates the integrated effect of reservoir fluid dilution and reservoir temperature decline during utilization. The chloride concentrations $\left(\mathrm{Cl}^{-}\right)$were corrected to compensate for the steam loss. All fractions shown in the diagram originate from the geothermal source parent fluid, which was estimated to have a chloride concentration of $1600 \mathrm{ppm}$ and an enthalpy of $870 \mathrm{~kJ} / \mathrm{kg}$ (corresponding to $204{ }^{\circ} \mathrm{C}$ ). The most diluted well waters are 106, 108, and RE1, where the meteoric water fraction is estimated to be 40-62.5\%, and the fluid enthalpy drops to $680-730 \mathrm{~kJ} / \mathrm{kg}$. Wells $121,122,123$ and 103 are less sensitive to meteoric water inflows; the dilution rate is estimated to be $30-39.5 \%$, and the enthalpy decline to $740-850 \mathrm{~kJ} / \mathrm{kg}$. Wells GK3 and 120 indicate a dilution of 13-39.5\%, with fluid enthalpies in the 790-890 $\mathrm{kJ} / \mathrm{kg}$ range, and a relatively slow decline rate. Stable isotope data $\left(\delta \mathrm{D}, \delta^{18} \mathrm{O}\right)$ and tritium data confirm a significant meteoric inflow into the geothermal reservoir during utilization. Hence, the key feature of the Pauzhetsky field behavior is the cooling of the production wells, accompanied by a change in fluid chemistry and temperatures along streamlines which starts at the recharge areas. The cooling rates can be approximately correlated with the relative horizontal distances between the producing wells and the recharge areas, rather than the depths of the feed zones in the wells. For example, Wells 106, 108, and RE1, which are located closer to the recharge areas, show faster enthalpy and chloride declines 
than wells 121, 122, 123 and 103, which are farther away from the infiltration zones. The location of meteoric water inflows basically coincides with pre-utilization discharge areas, i.e. fractured and/or faulted zones that allow a hydraulic communication between the geothermal reservoir and the water-saturated alluvial deposits of the Pauzhetka River and tributary creeks. The pressure drop caused by utilization turned these areas into distinct infiltration/recharge zones in the northern, western, and eastern parts of the field, surrounding the production zone in the center. There is also a possibility that some abandoned, poorly cemented wells allow the inflow of shallow groundwater into the geothermal reservoir.

\section{Conclusions}

Mechanisms of Kamchatka geothermal reservoir functionality were studied by using isotope and geochemistry data: (1) The Geysers Valley hydrothermal reservoirs shows a key role of cyclic $\mathrm{CO}_{2}$ inflow on geysers functionality; (2) The Paratunsky low temperature reservoirs recharge areas were indicated by water isotope data, while a chloride rise pointed to utilization-induced recharge from the west boundary, where a potential adjacent geothermal reservoir may exist; (3) The North-Koryaksky hydrothermal system is recharged by meteoric water from the Koryaksky volcano glaciers and magmatic $\mathrm{CO}_{2}$, as revealed by isotopes of water and carbon-13 (in $\mathrm{CO}_{2}$ ) data; (4) The Mutnovsky high temperature geothermal reservoir is initially fed by the water from the Mutnovsky volcano glacier, then utilization triggers a local meteoric water inflow (water isotope data, $\mathrm{Cl}^{-}$ transient data); (5) The Pauzhetsky medium temperature geothermal reservoir is significantly diluted by local meteoric waters, which used former discharge channels to flow in $\left(\mathrm{Cl}^{-}\right.$transient data).

We also mentioned $\mathrm{SiO}_{2}$ and $\mathrm{Na}-\mathrm{K}$ geothermometers as useful tools to predict temperatures in all the above mentioned reservoirs, but opposite time transient trends of these geothermometers (Paratunsky, Geysers Valley). This points to the necessity of using additional geothermeters in the future, such as more sophisticated methods relying on multicomponent water/mineral equilibria.

This work is supported by RFBR grant \# 18-05-00052. Authors appreciate useful suggestions of Nicolas Spycher, Halldór Ârmannsson and one unknown reviewer.

\section{References}

1. A.V. Kiryukhin, T.V. Rychkova, I.K. Dubrovskaya, Applied Geochemistry 27, 17531766 (2012)

2. A. Kiryukhin. Journal of Volcanology and Geothermal Research, 323, 129-147 (2016)

3. A. Kiryukhin, V. Sugrobov, E. Sonnenthal. Geofluids Journal, Article ID 1963618 (2018)

4. A.V. Kiryukhin, L.A. Vorozheikina, P.O.Voronin, P.A. Kiryukhin Geothermics 70, 4761 (2017)

5. A. Kiryukhin, V. Lavrushin, P. Kiryukhin, P. Voronin. Geofluids Journal. Article ID 4279652 (2017)

6. A.V. Kiryukhin, A.Y. Polyakov, O.O. Usacheva, P.A. Kiryukhin. Journal of Volcanology and Geothermal Research, 356, 36-55 (2018)

7. A.V. Kiryukhin, V.A. Yampolsky. Geothermics, v.33, No.4, 421-441 (2004)

8. A.V. Kiryukhin, N.P. Asaulova, S. Finsterle, Geothermics, V. 37, 540-562 (2008) 